\title{
Неврологічні скарги та їх характеристики в пацієнтів із глаукомою
}

\begin{abstract}
Резюме. Актуальність. Загальновідомим є те, що офтальмологічні розлади вельми часто є наслідком ураження різноманітних нервових структур, і тому їх дослідження може сприяти уточненню таких уражень. Метою роботи було дослідження неврологічних скарг та їх характеристик у пацієнтів із глаукомою. Матеріали та методи. Наведено результати фрагмента комплексного обстеження 60 осіб із глаукомою, що включало: детальне неврологічне обстежсення з вивченням скарг, даних клініко-неврологічного обстеження з визначенням та порівнянням основних неврологічних синдромів, оцінку показників нейропсихологічного статусу, вегетативного забезпечення та показників центральної гемодинаміки. Вік обстежених пацієнтів становив від 51 до 89 років. Середній вік обстежених - 68,0 \pm 7,9 року. Контингент включав осіб середнього, похилого та старечого віку. Дещо переважсали жінки - 34 особи (56, 7 \%), чоловіків було відповідно 26 осіб (43,3\%). Результати. При клініко-неврологічному обстеженні пацієнтів із глаукомою був виявлений ряд особливостей: встановлено, що головний біль визначався в 63,3 \% пацієнтів, більше ніж у половини пацієнтів із глаукомою були виявлені різноманітні вегетативні порушення, ознаки порушення з боку психоемоційної сфери та порушення сну. Увсіх обстежсених пацієнтів із глаукомою був підвищений рівень конституційної та ситуаційної тривожності. Висновки. Виявлені клініко-неврологічні особливості та порушення з боку психоемоційної сфери в пацієнтів із глаукомою зумовлюють потребу подальшого детального дослідження.
\end{abstract}

Ключові слова: глаукома; клініко-неврологічні характеристики; нейропсихологічні характеристики

\section{Вступ}

Зоровий аналізатор, що філоонтогенетично, ембріонально та морфологічно пов'язаний із нервовою системою, фактично є ії складовою. Особливості будови зорової системи демонструють певну штучність ії відокремлення від нервової системи. Загальновідомим є те, що офтальмологічні розлади дуже часто є наслідком ураження різноманітних нервових структур, і тому їх дослідження може сприяти уточненню таких уражень. Це обумовлює актуальність комплексного клініконеврологічного і нейроофтальмологічного обстеження пацієнтів, що, з одного боку, може сприяти вивченню неврологічних і соматоневрологічних уражень, а 3 іншого боку, оскільки на виникнення та перебіг тих захворювань, які вважаються суто офтальмологічними, зокрема глаукоми, вагомий вплив здійснює нервова система (здебільшого іiї вегетативний відділ), уточнити патогенетичні механізми зазначених патологій.

За даними Всесвітньої організації охорони здоров’я, у 2010 році у світі налічувався 161 млн осіб із порушенням зору, серед них 39 млн були сліпими та потребували професійно-технічної та соціальної підтримки. Кількість таких хворих має тенденцію до зростання. Прогнозується що, у 2020 році їх буде вже понад 76 млн осіб [1].

За результатами епідеміологічних досліджень, практично у всіх регіонах світу серед причин сліпоти друге місце посідає глаукома, що підкреслює ії соціальну значущість, зокрема, як одного з інвалідизуючих захворювань [1].

У 2010 році кількість хворих на глаукому становила 60,5 млн осіб, а за прогнозами до 2020 року ця кількість зросте до 79,6 млн осіб.

В історичному плані протягом багатьох років існували досить спрощенні погляди на дане захворювання. А уявлення про сутність глаукоми змінювалось під час удосконалення діагностики при використанні сучасного обладнання та з урахуванням результатів все нових досліджень. Ще в минулому сторіччі A. Graefe зміг виділити характерну для глаукоми тріаду симптомів: підвищення внутрішньоочного тиску (ВОТ) (офтальмогіпертензія), специфічне біназальне звуження поля зору, крайова екскавація диска зорового нерва (ДЗН) [2, 3].

(c) «Архів офтальмологіїУкраїни» / «Архив офтальмологии Украины» / «Archive Of Ukrainian Ophthalmology» («Arhìv oftal'mologiï Ukraïni»), 2018

(c) Видавець Заславський 0.Ю. / Издатель Заславский А.Ю. / Publisher Zaslavsky 0.Yu., 2018

Для кореспонденції: Ткаченко 0.В., Національна медична академія післядипломної освіти імені П.Л. Шупика, вул. Дорогожицька, 9, м. Київ, 04112, Україна; е-таil: redact@i.uа For correspondence: 0. Tkachenko, Shupyk National Medical Academy of Postgraduate Education, Dorohozhytska st., 9, Kyiv, 04112, Ukraine; e-mail: redact@i.ua 
В подальшому було встановлено, що при глаукомі відбувається склерозування дренажної системи ока, і як наслідок - погіршення очної гідро- та гемодинаміки, зміни в райдужній оболонці, кришталику, судинному руслі епісклери тощо. Зважаючи на те, що цей процес може мати універсальне підгрунтя з рядом процесів неврологічної дисфункції, дослідження неврологічного аспекту цієї проблеми сприятиме уточненню патогенетичних механізмів, що супроводжують виникнення глаукомної нейропатії [3-5].

Існує низка теорій і гіпотез щодо механізмів виникнення і розвитку глаукоми. Серед них механічна теорія розвитку атрофії, ішемічна теорія тощо [4-6, 8].

На сьогодні серед підходів до діагностичних критеріїв глаукоми домінуючим $є$ такий, що поставив під сумнів роль підвищеного ВОТ як основного діагностичного критерію. Установлено глаукому і при нормальному ВОТ, але за наявності типової оптичної нейропатії ДЗН. Такий тип глаукоми називають глаукомою нормального тиску або нормотензивною глаукомою [3, 5-7].

Зазначений підхід із позиції неврології не є таким однозначним як щодо термінологічного, так і патогенетичного аспектів ураження, тому як мінімум потребує подальших досліджень і обговорень.

3 урахуванням зазначеного важливим для уточнення патогенетичних особливостей патології є дослідження анамнестичних даних, скарг із боку нервової системи, клініко-неврологічних і нейропсихологічних характеристик у пацієнтів із глаукомою.

Надано фрагмент комплексного дослідження неврологічних характеристик, що стосується неврологічних скарг у хворих на глаукому. Проведені детальне опитування щодо наявності скарг із боку нервової системи й оцінка отриманих даних. Фіксували й аналізували скарги, що пацієнти надавали ініциативно, а також ті, що були отримані в результаті цілеспрямованого опитування з використанням опитувальника.

Мета роботи: дослідити неврологічні скарги та їх характеристики в пацієнтів із глаукомою.

\section{Матеріали та методи}

Наведено результати фрагмента комплексного обстеження 60 осіб із глаукомою, що включало: детальне неврологічне обстеження з вивченням скарг, даних клініко-неврологічного обстеження 3 визначенням та зіставленням основних неврологічних синдромів, оцінку показників нейропсихологічного статусу, вегетативного забезпечення та показників центральної гемодинаміки.

Всі пацієнти спостерігались у офтальмолога та дотримувались отриманих рекомендацій щодо корекції рівня внутрішньоочного тиску. Вік обстежених пацієнтів становив від 51 до 89 років. Середній вік обстежених $-68,0 \pm 7,9$ року. Контингент включав осіб середнього, похилого та старечого віку. Дещо переважали жінки - 34 особи $(56,7 \%)$, чоловіків було відповідно 26 осіб (43,3\%). Усі пацієнти проходили обстеження на клінічній базі кафедри неврології № 2 Національної медичної академії післядипломної освіти імені
П.Л. Шупика, в київській міській клінічній лікарні № 12 та перебували під спостереженням у офтальмологів на базі київської клінічної офтальмологічної лікарні «Центр мікрохірургії ока».

Статистична обробка даних здійснювалась за допомогою стандартного програмного пакета Statistica 10. Оцінку змін показників проводили за допомогою t-критерію Стьюдента (рівень вірогідності $-\mathrm{p}<0,05)$.

\section{Результати та обговорення}

За скаргами обстежених пацієнтів із глаукомою нами було встановлено, що на головний біль при детальному опитуванні скаржились 38 (63,3\%) пацієнтів, серед них 21 (53,3\%) жінка та 17 (44,7 \%) чоловіків. Проте самостійно скарги на головний біль пред'явили лише 24 (40 \%) хворі. Скарги, що характеризували наявність вегетативних порушень, виявлено в 36 (60 \%) обстежених. При цьому вказані скарги виявлялись у 20 жінок (в 55,6 \% випадків) та в 16 чоловіків (в 44,4\% випадків). Самостійно скарги, що характеризували наявність вегетативних порушень, пред'явили 9 (15\%) осіб. Скарги, що відображали наявність психоемоційних розладів, були в 33 (55 \%) пацієнтів. У гендерному співвідношенні щодо цих розладів переважали жінки (відповідно 69,7 \% - жінки, 30,3 \% - чоловіки). 15 (25\%) пацієнтів із глаукомою дані скарги пред'явили самостійно, інші (18 осіб - 30 \%) виявились при детальному опитуванні. Порушення сну при опитуванні відмічали 30 (50 \%) пацієнтів, але активні скарги на порушення сну пред'являли лише 10 (17\%) пацієнтів із глаукомою, що подано на рис. 1.

Серед скарг, що можна було пов'язати з вегетативною дисфункцією, частіше зустрічались такі: на швидку втомлюваність поскаржились $16 \%$; інтестинальні прояви вегетативної дисфункції відмітили 14 \%; оніміння в кінцівках спостерігалось у $12 \%$ випадків; схильність до почервоніння або збліднення обличчя у 12 \% пацієнтів; вегетативна дисфункція за кардіальним типом у вигляді відчуття серцебиття, завмирання або зупинки серця відмічалась у $12 \%$ пацієнтів; $8 \%$

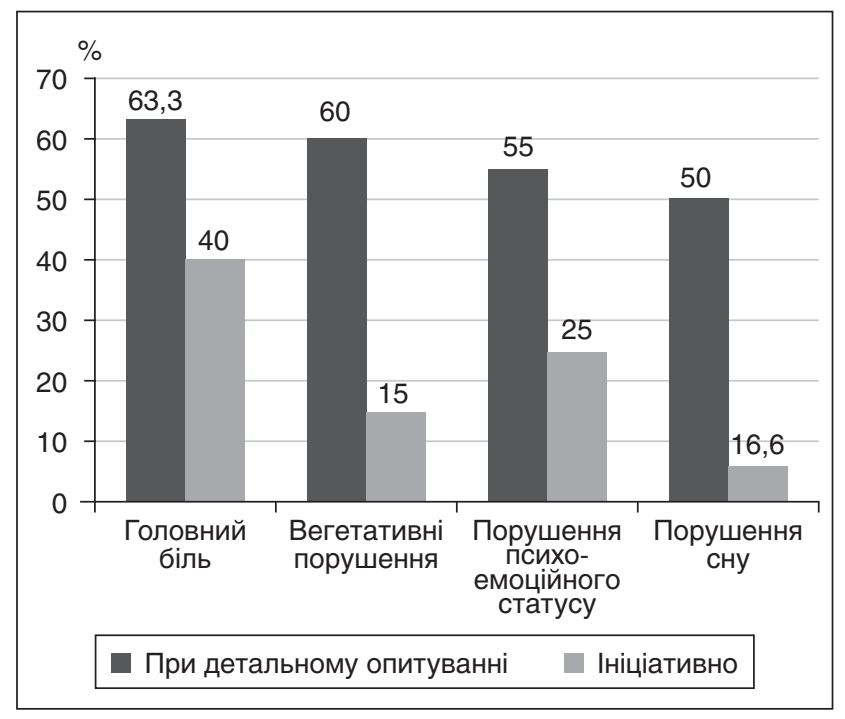

Рисунок 1. Частота скарг у пацієнтів із глаукомою 


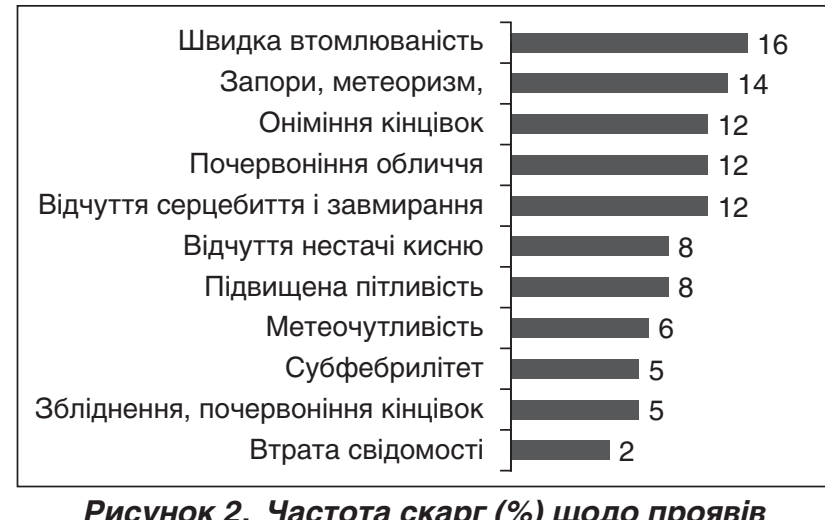
вегетативної дисфункції в паціснтів із глаукомою

пацієнтів відмітили вегетативну дисфункцію з респіраторними проявами (а саме відчуття нестачі повітря, тахіпное тощо); 8 \% хворих скаржились на підвищену пітливість; 6 \% - помітили метеочутливість; у $5 \%$ спостерігався періодичний субфебрилітет; 5 \% пацієнтів відмітили періодичні прояви ангіотрофоневрозу у вигляді зміни кольору (почервоніння, збліднення, синюшність) пальців кистей та стоп; у $2 \%$ - були епізоди запаморочення (рис. 2).

При дослідженні скарг на головний біль, що відмічали 38 (63,3 \%) пацієнтів із глаукомою, переважала помірна інтенсивність головного болю за евалюативною шкалою опитувальника McGill Pain Questionnaire - у $30(79 \%)$ випадках, $11 \%$ відзначили головний біль як сильний. Проте жоден обстежений не відзначав за цією шкалою таку інтенсивність болю, як найсильніший чи нестерпний (рис. 3).

За 10-бальною шкалою оцінки інтенсивності головного болю в пацієнтів із глаукомою частіше виявлявся біль інтенсивністю 4 бали (табл. 1).

Звертав на себе увагу той факт, що інтенсивність болю у 8-10 балів (за 10-бальною шкалою оцінки інтенсивності головного болю) серед обстежених не була відмічена. Тобто існує певна кореляція оцінок інтенсивності болю за шкалою опитувальника McGill Pain

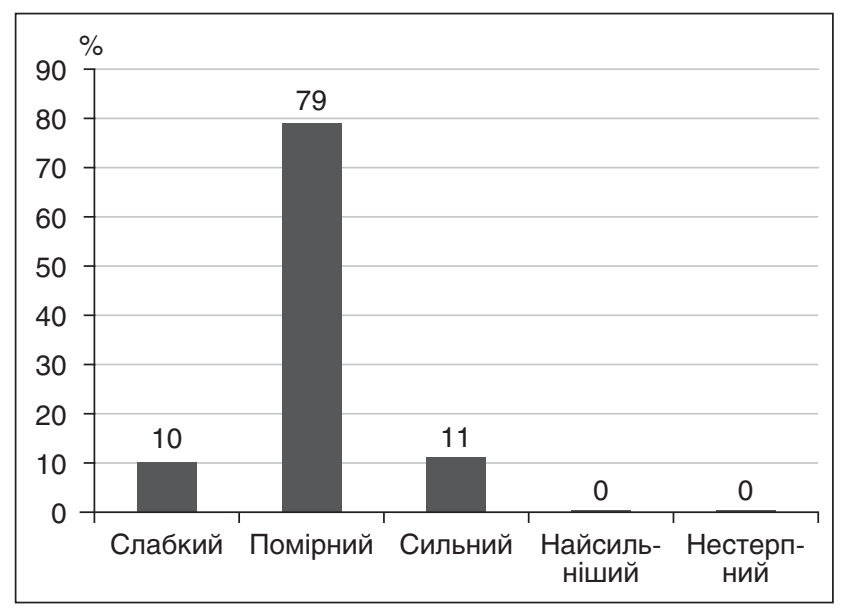

Рисунок 3. Частота різної інтенсивності головного болю в пацієнтів із глаукомою (згідно з опитувальником McGill Pain Questionnaire)
Таблиця 1. Розподіл пацієнтів згідно з 10-бальною шкалою оцінки інтенсивності головного болю

\begin{tabular}{|c|c|}
\hline Інтенсивність, бали & $\begin{array}{c}\text { Кількість пацієнтів, } \\
\mathbf{n}(\%)\end{array}$ \\
\hline 2 & $5(13,2)$ \\
\hline 3 & $7(18,4)$ \\
\hline 4 & $14(36,8)$ \\
\hline 5 & $8(21,1)$ \\
\hline 6 & $3(7,9)$ \\
\hline 7 & $1(2,6)$ \\
\hline
\end{tabular}

Questionnaire та 10-бальної шкалою оцінки інтенсивності головного болю.

При оцінюванні характеристик головного болю за допомогою опитувальника болю McGill Pain Questionnaire в сенсорному дескрипторі в пацієнтів із глаукомою було виявлено, що в обстежених нами пацієнтів частіше зустрічались такі характеристики головного болю, як тиснучий $(17,9 \%)$ та розпираючий $(17,9 \%)$. Головний біль тупого характеру відмічався в 13,2 \% осіб, з такою ж частотою спостерігався ниючий головний біль. Рідше зустрічався пульсуючий та спазмоподібний головний біль - відповідно у 8 та 5 \% пацієнтів. Частота інших типів головного болю: розлитого, пекучого, стягуючого, колючого, гострого, ріжучого та інших - становила окремо до 1-3\% (рис. 4).

При оцінці психоемоційних характеристик головного болю в афективному дескрипторі було виявлено, що в пацієнтів із глаукомою превалював біль втомлюючого характеру - 25,8 \% випадків, а також біль знесилюючого характеру - 17,2 \% випадків. Найрідше зустрічався головний біль-страждання - в 1,72 \% пацієнтів. Частота кожного з інших типів головного болю, зокрема, біль, що викликає відчуття нудоти, страху, біль що пригнічує, біль-страждання та інші, становила менше ніж по 5 \%, а загалом вони становили 24,3 \% (рис. 5 ).

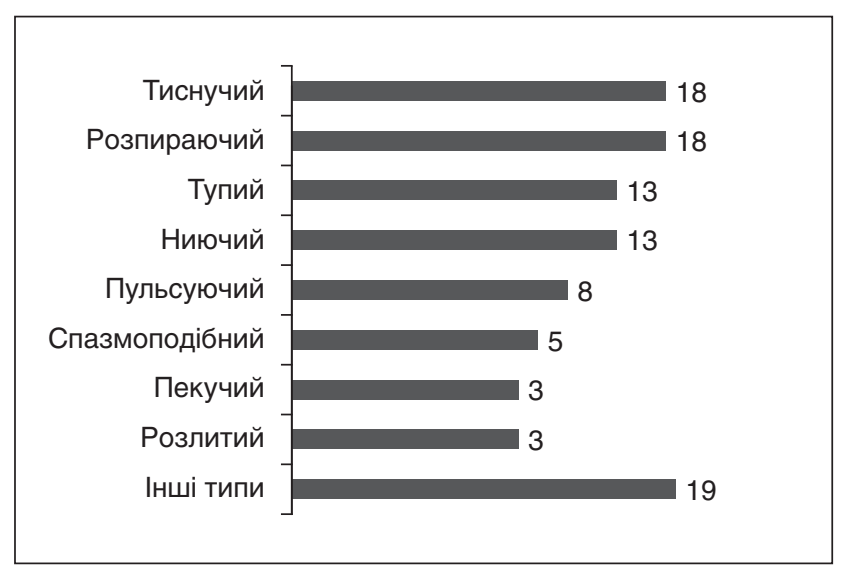

Рисунок 4. Характеристики головного болю в пацієнтів із глаукомою згідно з опитувальником болю McGill Pain Questionnaire (сенсорний дескриптор) 


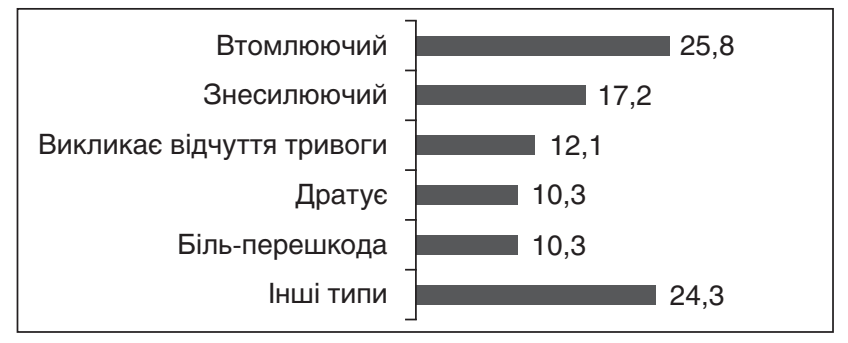

Рисунок 5. Психоемоційні характеристики головного болю в пацієнтів із глаукомою згідно з опитувальником болю McGill Pain Questionnaire (афективний дескриптор)

У всіх обстежених пацієнтів із глаукомою був підвищений рівень конституційної та ситуаційної тривожності згідно з результатами опитувальників тривожності Спілбергера - Ханіна.

При проведенні кореляційного аналізу між інтенсивністю головного болю та рівнем ситуаційної тривожності в пацієнтів із глаукомою був виявлений сильний прямий кореляційний зв'язок $(\mathrm{t}=8,1 \mathrm{p}<0,01)$. Такий же зв'язок простежувався між інтенсивністю головного болю та рівнем конституційної тривожності $(\mathrm{t}=7,5 \mathrm{p}<0,01)$.

\section{Висновки}

При детальному комплексному клініко-неврологічному обстеженні пацієнтів із глаукомою був виявлений ряд особливостей: встановлено, що головний біль відмічався в 63,3 \% пацієнтів, при цьому превалював тиснучий та розпираючий його характер (згідно із сенсорним дескриптором опитувальника болю McGill Pain Questionnaire), а також втомлюючий та знесилюючий (згідно з афективним дескриптором опитувальника болю McGill Pain Questionnaire). Більше ніж у половини пацієнтів із глаукомою були виявлені різноманітні вегетативні порушення, ознаки порушення 3 боку психоемоційної сфери та порушення сну. В усіх пацієнтів із глаукомою, які відмічали різної інтенсив- ності головний біль, спостерігався підвищений рівень конституційної та ситуаційної тривожності, при цьому був наявний сильний, прямий кореляційний зв'язок між вказаними явищами. Виявлені клініко-неврологічні особливості в пацієнтів із глаукомою зумовлюють потребу подальшого детального дослідження.

Конфлікт інтересів. Автори заявляють про відсутність конфлікту інтересів при підготовці даної статті.

\section{Список мітератури}

1. Quigley H.A. The number of people with glaucoma worldwide in 2010 and 2020 / H.A. Quigley, A.T. Broman // Br. J. Ophthalmol. - 2006. - Vol. 90. - P. 262-267.

2. Gupta N. New definitions of glaucoma / N. Gupta, R.N. Weinreb // Curr. Opin. Ophthalmol. - 1997. - Vol. 8. - P. 38-41.

3. Disease progression and the need for neuroprotection in glaucoma management / R. Varma, P. Peeples, Jg Walt et al. // Am. J. Manag. Care. - 2008. - Vol. 14. - P. 15-19.

4. Casson R.J. Possible role of excitotoxicity in the pathogenesis of glaucoma / R.J. Casson // Experiment. Ophthalmol. - 2006. Vol. 34(1). - P. 54-63.

5. Logan J.F. Retinal blood flow measurements and neuroretinal rim damage in glaucoma / J.F. Logan, S.J. Rankin, A.J. Jackson // Br. J. Ophthalmol. - 2004. - Vol. 88. - P. 1049-1054.

6. Retinal oxidative stress induced by high intraocular pressure / M.C. Moreno, J. Campanelli, P. Sande et al. // Free Radic. Biol. Med. - 2004. - Vol. 37. - P. 803-812.

7. Low-Pressure Glaucoma Study Group. A randomized trial of brimonidine versus timolol in preserving visual function: results from the Low-Pressure Glaucoma Treatment Study / T. Krupin, J.M. Liebmann, D.S. Greenfield et al. // Am. J. Ophthalmol. 2011. - Vol. 151. - P. 671-681.

8. High prevalence of anxiety and depression in patients with primary open-angle glaucoma / F. Mabuchi, K. Yoshimura, K. Kashiwagi et al. // J. Glaucoma. - 2008. - Vol. 17. - P. 552-557.

Отримано 13.10.2018

Ткаченко Е.В., Рыков С.О., Шаргородская И.В., Масович С.О.

Национальная меАицинская акаАемия послеАипломного образования имени П.А. Шупика МЗ Украины, г. Киев, Украина

\section{Неврологические жалобы и их характеристики у пациентов с глаукомой}

Резюме. Актуальность. Общеизвестным является то, что офтальмологические расстройства весьма часто являются следствием поражения различных нервных структур, и поэтому их исследование может способствовать уточнению таких поражений. Целью работы было исследование неврологических жалоб и их характеристик у пациентов с глаукомой. Материалы и методы. Приведены результаты фрагмента комплексного обследования 60 пациентов с глаукомой, которое включало: детальное неврологическое исследование с изучением жалоб, данных клинико-неврологического обследования с изучением и сопоставлением основных неврологических синдромов, оценку показателей нейропсихологического статуса, вегетативного обеспечения и показателей центральной гемодинамики. Возраст обследованных пациентов составлял от 51 до 89 лет. Средний возраст обследованных $68,0 \pm 7,9$ года. Контингент включал лиц среднего, пожилого и старческого возраста. Незначительно преобладали женщины - 34 (56,7 \%), мужчин соответственно, было 26 (43,3 \%). Результаты. При клинико-неврологическом обследовании пациентов с глаукомой был обнаружен целый ряд особенностей: установлено, что головная боль выявлялась у 63,3 \% пациентов, больше чем у половины пациентов с глаукомой были обнаружены разнообразные вегетативные нарушения, признаки нарушения со стороны психоэмоциональной сферы и нарушения сна. У всех обследованных пациентов с глаукомой был повышен уровень конституциональной и ситуационной тревожности. Выводы. Выявленные клиниконеврологические особенности и нарушения со стороны психоэмоциональной сферы у пациентов с глаукомой обусловливают необходимость дальнейшего детального исследования. Ключевые слова: глаукома; клинико-неврологические характеристики; нейропсихологические характеристики 
O.V. Tkachenko, S.A. Rykov, I.V. Shargorodska, S.O. Masovych

Shupyk National Medical Academy of Postgraduate Education, Kyiv, Ukraine

\section{Neurological complaints and their features in glaucoma patients}

Abstract. Background. It is generally accepted that ophthalmological disorders quite frequently result from various central nervous system impairments; therefore, their assessment may lead to further detection of such lesions. The purpose was the assessment of neurological complaints and their features in glaucoma patients. Materials and methods. The article presents a fragment of comprehensive examination in 60 glaucoma patients, including: detailed neurological examination with complaints and clinical neurologic findings assessment, further determination and comparison of main neurological syndromes, neuropsychological status, vegetative state and central hemodynamic parameters. The age of the examined patients varied from 51 to 89 years, with an average of $68.0 \pm 7.9$ years. The cohort consisted of middle-aged, elderly and senile patients. Females prevailed slightly -34 persons $(56.7 \%)$, and 26 males, respectively (43.3\%). Results. Based on the glaucoma patients complaints we determined that $38(63.3 \%)$ individuals $(21$ (53.3\%) females and 17 (44.7\%) males) complained of headaches. However, only 24 (40\%) patients reported their complaints personally. Vegetative disorder-related complaints were detected in 36 $(60 \%)$ patients. However, complaints appeared predominantly in females $-20(55.6 \%)$ (and in $16(44.4 \%)$ males). Vegetative disorder-related complaints were reported by $9(15 \%)$ patients personally. Complaints indicative of psychoemotional disorders occurred in $33(55 \%)$ persons. Females prevailed in gender ratio regarding there disorders ( 69.7 vs $30.3 \%$ ). Fifteen ( $25 \%$ ) glaucoma patients reported the above-mentioned complaints by themselves, the other
$18(30 \%)$ - during detailed questioning. Sleep disturbances were detected by $30(50 \%)$ patients; however, only $10(17 \%)$ patients reported active complaints of sleep disturbances. Different vegetative disorders, signs of psychoemotional and sleep disturbances were detected in more than a half of glaucoma patients. Levels of constitutional and situational anxiety were increased in all examined patients. Correlation analysis conducted between the headache severity and situational anxiety level in glaucoma patients revealed direct, strong correlation $(\mathrm{t}=8.1, \mathrm{p}<0.01)$. Similar correlation was determined between the headache severity and constitutional anxiety level $(\mathrm{t}=7.5, \mathrm{p}<0.01)$. Conclusions. Detailed comprehensive clinical neurologic examination in glaucoma patients revealed following features: it was found that headaches tended to occur in $63.3 \%$ of patients, while the pressing and bursting headache was prevalent (as defined in the sensory descriptor of McGill Pain Questionnaire), distressing and debilitating as well (as defined in the affective descriptor of McGill Pain Questionnaire). Different vegetative disorders, signs of psychoemotional and sleep disturbances were detected in more than a half of glaucoma patients. Levels of constitutional and situational anxiety were increased in all glaucoma patients who reported headaches of varying severity; moreover, the direct strong correlation was revealed between manifestations referred. Clinical neurologic features detected in glaucoma patients require further detailed studies.

Keywords: glaucoma; clinical neurologic features; neuropsychological features 